University of Nebraska - Lincoln

DigitalCommons@University of Nebraska - Lincoln

Comparison of Field Measured Soil Absorption Field Loading Rates and Loading Rates Estimated from Soil Morphologic Properties

\author{
Kelli S. Hart \\ NewFields Agricultural and Environmental Resources \\ Brad D. Lee \\ Purdue University \\ Philip J. Schoeneberger \\ USDA \\ Donald P. Franzmeier \\ Purdue University \\ Phillip R. Owens \\ Purdue University \\ See next page for additional authors
}

Follow this and additional works at: https://digitalcommons.unl.edu/usdaarsfacpub

Part of the Agricultural Science Commons

\begin{abstract}
Hart, Kelli S.; Lee, Brad D.; Schoeneberger, Philip J.; Franzmeier, Donald P.; Owens, Phillip R.; and Smith, Douglas R., "Comparison of Field Measured Soil Absorption Field Loading Rates and Loading Rates Estimated from Soil Morphologic Properties" (2008). Publications from USDA-ARS / UNL Faculty. 472. https://digitalcommons.unl.edu/usdaarsfacpub/472
\end{abstract}

This Article is brought to you for free and open access by the U.S. Department of Agriculture: Agricultural Research Service, Lincoln, Nebraska at DigitalCommons@University of Nebraska - Lincoln. It has been accepted for inclusion in Publications from USDA-ARS / UNL Faculty by an authorized administrator of DigitalCommons@University of Nebraska - Lincoln. 


\section{Authors}

Kelli S. Hart, Brad D. Lee, Philip J. Schoeneberger, Donald P. Franzmeier, Phillip R. Owens, and Douglas R. Smith 


\title{
Comparison of Field Measured Soil Absorption Field Loading Rates and Loading Rates Estimated from Soil Morphologic Properties
}

\author{
Kelli S. Hart'; Brad D. Lee ${ }^{2}$; Philip J. Schoeneberger ${ }^{3}$; Donald P. Franzmeier ${ }^{4}$; Phillip R. Owens ${ }^{5}$; and \\ Douglas R. Smith ${ }^{6}$
}

\begin{abstract}
Concerns from local health departments regarding premature septic system failure (less than 1 year from installation) has led to an investigation of septic system soil absorption field design parameters in northeast Indiana. The objective of this study was to compare the loading rate based on field measured saturated hydraulic conductivity $\left(\mathrm{LR}_{m}\right)$ across a toposequence to the estimated allowable loading rate $\left(\mathrm{LR}_{e}\right)$ based on soil morphological properties. Saturated hydraulic conductivity measurements were determined by a compact constant-head permeameter at five landscape positions, at four depths (surface horizon, upper argillic horizon, transition zone between the argillic horizon and till parent material, and till). Results showed that for all depths, the $\mathrm{LR}_{m}$ was smaller than $\mathrm{LR}_{e}$. Results from this study suggest that the current method of using soil morphological properties to determine the loading rate may overestimate the ability of the soil to properly disperse septic system effluent.
\end{abstract}

DOI: 10.1061/(ASCE)1084-0699(2008)13:8(665)

CE Database subject headings: Hydraulic conductivity; Loading rate; Wastewater management; Soils; Comparative studies; Absorption.

\section{Introduction}

Approximately one-third of the homes in Indiana use septic systems, leading to the soil treatment of more than 195 billion L of household wastewater effluent per year (Taylor et al. 1997). Indiana state regulations require all septic systems to discharge wastewater effluent into the soil (ISDH 1990). The most common septic system design throughout the state is a conventional trench system, which contains a septic tank, distribution box, and soil absorption field. The soil absorption field includes a series of parallel trenches containing perforated distribution pipes surrounded by gravel. Wastewater from the home is clarified in the

\footnotetext{
${ }^{1}$ Staff Scientist, NewFields Agricultural and Environmental Resources, LLC, 304 S St., Suite 101, Sacramento, CA 95811; formerly, CH2M Hill, 2485 Natomas Park Dr., Sacramento, CA 95833.

${ }^{2}$ Associate Professor, Agronomy Dept., Purdue Univ., 915 W. State St., West Lafayette, IN 47907-1150. E-mail: bdlee@ purdue.edu

${ }^{3}$ Research Soil Scientist, USDA NRCS National Soil Survey Laboratory, 100 Centennial Mall North, Room 152, Lincoln, NE 68508-3866. E-mail: Philip.schoeneberger@lin.usda.gov

${ }^{4}$ Professor Emeritus, Agronomy Dept., Purdue Univ., 915 W. State St., West Lafayette, IN 47907-1150. E-mail: dfranzmeier@purdue.edu

${ }^{5}$ Assistant Professor, Agronomy Dept., Purdue Univ., 915 W. State St., West Lafayette, IN 47907-1150. E-mail: prowens@purdue.edu

${ }^{6}$ Soil Scientist, USDA ARS National Soil Erosion Research Laboratory, 275 S. Russell St., West Lafayette, IN 47907. E-mail: drsmith@purdue.edu

Note. Discussion open until January 1, 2009. Separate discussions must be submitted for individual papers. To extend the closing date by one month, a written request must be filed with the ASCE Managing Editor. The manuscript for this paper was submitted for review and possible publication on July 6, 2006; approved on June 21, 2007. This paper is part of the Journal of Hydrologic Engineering, Vol. 13, No. 8, August 1, 2008. @ASCE, ISSN 1084-0699/2008/8-665-670/\$25.00.
}

septic tank where solids are retained through a density gradient. Once the effluent moves into the soil, the remaining organic constituents are removed through natural soil processes. In order for these processes to occur, the septic tank effluent must be able to move out into the soil at a rate that is sufficient to disperse the effluent through the soil at a rate greater than wastewater production from the household.

According to ISDH (1990), septic system soil absorption fields are designed based on three soil morphological characteristics: soil color, texture, and structure. Soil color is used to indicate the depth of the seasonally high water table. If the soils are sufficiently thick above a massive horizon, fragipan, dense glacial till, or rock $(51 \mathrm{~cm}$ for a mound or $83 \mathrm{~cm}$ for subsurface trench system), apparent seasonally high water tables identified by gray colors, will not prohibit the installation of a septic system as long as a subsurface drain adjacent to the soil absorption field can be used. Soil structure and texture properties are used to estimate the soil loading rate, which is the allowable rate of application of septic tank effluent to the soil (Table 1). The loading rate table currently used to determine the size of individual on-site systems was built using data from soils in Wisconsin and other Midwestern states. These data, along with soil characterization data from Purdue University, were used to derive an empirical equation that estimates the loading rate of the soil based on structure and texture (Taylor et al. 1997). Hydraulic conductivity and loading rate differ due to the fact that $K_{\text {sat }}$ assumes isotropic flow and loading rate estimates are based on trench bottom area. Loading rates are lower than $K_{\text {sat }}$ due to the reduction of wastewater infiltration at the soil and trench interface caused by biomat development.

Biomats form as a result of microbial growth at the trench-soil interface due to organic carbon load in the wastewater. In sandy soils, biomats are the most restrictive factor and control effluent dispersal in the soil absorption field. In fine-textured soils, the 


\begin{tabular}{|c|c|c|c|c|c|c|c|c|}
\hline \multirow[b]{2}{*}{ Soil texture class } & \multicolumn{8}{|c|}{ Soil structural class } \\
\hline & $\begin{array}{l}\text { Single } \\
\text { grain }\end{array}$ & $\begin{array}{l}\text { Granular } \\
\text { platy }^{\mathrm{a}}\end{array}$ & $\begin{array}{l}\text { Strong: } \\
\text { angular, } \\
\text { subangular } \\
\text { blocky, } \\
\text { prismatic }\end{array}$ & $\begin{array}{l}\text { Moderate: } \\
\text { angular, } \\
\text { subangular } \\
\text { blocky, } \\
\text { prismatic }\end{array}$ & $\begin{array}{l}\text { Weak: } \\
\text { angular, } \\
\text { subangular } \\
\text { blocky, } \\
\text { prismatic }\end{array}$ & $\begin{array}{l}\text { Fragipan: } \\
\text { very } \\
\text { coarse } \\
\text { prismatic }\end{array}$ & $\begin{array}{l}\text { Structureless, } \\
\text { massive, } \\
\text { friable, vary } \\
\text { friable }\end{array}$ & $\begin{array}{l}\text { Structureless, } \\
\text { massive, } \\
\text { compact, firm, } \\
\text { very firm }\end{array}$ \\
\hline Gravel, coarse sand & 48.89 & $\mathrm{NLR}^{\mathrm{b}}$ & NLR & NLR & NLR & NLR & NLR & NLR \\
\hline Loamy coarse sand. medium sand & 48.89 & 48.89 & NLR & NLR & 48.89 & NLR & NLR & NLR \\
\hline Fine sand, loamy sand, loamy fine sand & 30.56 & 24.44 & NLR & 30.56 & 30.56 & NLR & 30.56 & NLR \\
\hline Very fine sand, loam very fine sand & 20.37 & 20.37 & NLR & 30.56 & 24.44 & NLR & 24.44 & NLR \\
\hline Sandy loam, coarse sandy loam & NLR & 30.56 & NLR & 24.44 & 24.44 & NLR & 24.44 & NLR \\
\hline Fine sandy loam, very fine sandy loam & NLR & 30.56 & NLR & 24.44 & 24.44 & NLR & 24.44 & NLR \\
\hline Sandy clay loam & NLR & 30.56 & 30.56 & 20.37 & 20.37 & NLR & 20.37 & NLR \\
\hline Loam & NLR & 30.56 & 30.56 & 20.37 & 12.22 & NLR & 12.22 & NLR \\
\hline Silt loam & NLR & 24.44 & 24.44 & 20.37 & 12.22 & NLR & 12.22 & NLR \\
\hline Silty clay loam, clay, loam, sandy clay & NLR & 24.44 & 24.44 & 12.22 & 10.19 & NLR & 10.19 & NLR \\
\hline Silty clay, clay & NLR & 24.44 & 20.37 & 12.22 & 10.19 & NLR & 10.19 & NLR \\
\hline Muck & NLR & NLR & NLR & NLR & NLR & NLR & NLR & NLR \\
\hline Marl, bedrock & NLR & NLR & NLR & NLR & NLR & NLR & NLR & NLR \\
\hline
\end{tabular}

${ }^{\mathrm{a}}$ Except where platy structure has been caused by soil compaction. Platy structure caused by compaction has a loading rate of $0.00 \mathrm{~L}$ day ${ }^{-1} \mathrm{~m}^{-2}$.

${ }^{\mathrm{b}} \mathrm{NLR}=$ no loading rate.

loading rate is lower; therefore, the absorption field needs to be larger. The larger absorption field allows the organic carbon load to be spread out over a larger soil surface area; thus, biomats are not a probable cause of premature septic system failure in finetextured soils. The Indiana State Department of Health (ISDH) states that the soil must have a loading rate between $10.19 \mathrm{~L} \mathrm{day}^{-1} \mathrm{~m}^{-2}$ and $48.89 \mathrm{~L} \mathrm{day}^{-1} \mathrm{~m}^{-2}$ to be suitable for a septic system.

Since measuring $K_{\text {sat }}$ in the field is a very time-consuming process, other methods for determining $K_{\text {sat }}$ are desirable. Computer models are becoming a popular tool in evaluating soil properties. Many models have been developed to estimate soil hydraulic properties from soil physical properties using empirical equations (Campbell 1974; Rogowski 1972; Clapp and Hornberger 1978; Shepard 1993). This study used SOILPAR 2.00 (Acutis and Donatelli 2003) to estimate $K_{\text {sat }}$ from two models. The first model below was developed by Puckett et al. (1985), using Ultisols formed in unconsolidated sediments from Alabama. They concluded $K_{\text {sat }}$ was mostly dependent on the percentage of clay and, therefore, the following equation was developed to estimate $K_{\text {sat }}$ :

$$
K_{\text {sat }}=4.36 \times 10^{-5} \times e^{-0.1975 \times \% \text { clay }}
$$

The second model was developed by Jabro (1992), using data from 350 soil samples collected from Southern Cooperation Bulletins with various textures, bulk densities, and hydraulic conductivities. The model was then calibrated with soils from Pennsylvania. It was determined that the sand variable was not significant and, therefore, the model was developed using bulk density, percent clay, and percent silt

$$
\begin{aligned}
\log \left(K_{\text {sat }}\right)= & 9.56-0.81 \log (\% \text { silt })-1.09 \log (\% \text { clay }) \\
& -4.64\left(\mathrm{~g} \mathrm{~cm}^{-3} \text { bulk density }\right)
\end{aligned}
$$

If these models prove to be applicable, county health departments will have a tool that will easily estimate $K_{\text {sat }}$ for septic systems. The objectives of this study were twofold:
1. To compare field loading rates based on hydraulic conductivity measured in situ $\left(\mathrm{LR}_{m}\right)$ to estimated ISDH morphological loading rates $\left(\mathrm{LR}_{e}\right)$ and determine if differences exist; and

2. To determine if existing $K_{\text {sat }}$ models can estimate soil $K_{\text {sat }}$ at five landscape positions across a toposequence.

\section{Materials and Methods}

\section{Environmental Setting}

The study site is located on the Wabash moraine in Wells County, approximately $2.4 \mathrm{Km}$ northeast of Bluffton, Indiana. The Wabash moraine is one of several ice margin deposits on the Bluffton Till Plain, which is a nearly flat to gently rolling glacial plain (Gray 2000). The bedrock below the moraine is Silurian limestone and dolomite (Wayne 1966). A toposequence was selected in an agricultural field under soybean (Glycine max), corn (Zea mays), and wheat (Triticum aestivum) rotation. The elevation of this site is approximately $255 \mathrm{~m}$. The climate of this area is a Mesic temperature regime and a Udic moisture regime. Average annual rainfall is $1,126 \mathrm{~mm}$ with an average summer temperature of $21^{\circ} \mathrm{C}$ and average winter temperature of $0.06^{\circ} \mathrm{C}$ (NCDC 2005).

\section{Field Methods}

One soil pit was excavated at five landscape positions: summit, shoulder, backslope, footslope, and toeslope (Fig. 1). Soils at the upper four landscape positions were classified as Blount (fine, illitic, mesic Aeric Epiaqualf). Soils at the toeslope were classified as Pewamo (fine, mixed, active, mesic typic Argiaquoll). Soils were sampled and described according to USDA-NRCS standards (Schoeneberger et al. 2002). Soil hydraulic conductivity $\left(K_{\text {sat }}\right)$ was measured in the field using the constant head well permeameter method (Amoozegar 1989). Hydraulic conductivity data were collected between 1 and $5 \mathrm{~m}$ of the soil pit face. A constant head of $15 \mathrm{~cm}$ was maintained to determine the $K_{\text {sat }}$ at four selected 


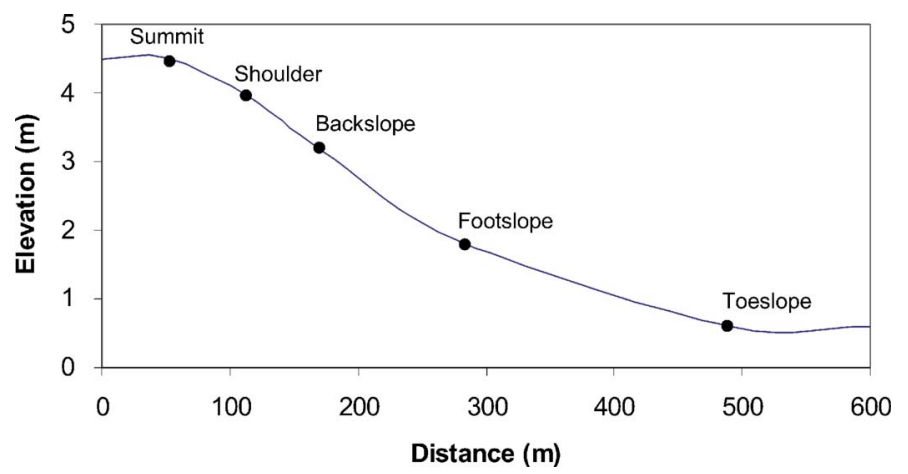

Fig. 1. Relative locations of soil pits and $K_{\text {sat }}$ data collection sites

horizons. Three to eight $K_{\text {sat }}$ replicate measurements were sampled per horizon at the five landscape positions.

\section{Laboratory Methods}

Soil samples were air dried and ground to separate $<2 \mathrm{~mm}$ fraction for texture analysis. Particle size was determined by the pipette method at the National Soil Survey Laboratory (NSSL) (3A1a1a) (Burt 2004). Intact soil clods were collected from each horizon for bulk density $\left(\mathrm{Db}_{\mathrm{OD}}\right)$ analysis by the oven-dry method using saran coated clods at the NSSL (3B1c) (Burt 2004).

\section{Data Analysis}

In order to compare the field measured $K_{\text {sat }}$ to the loading rate based on texture and structure, the measured $K_{\text {sat }}$ was converted to the loading rate using the following equation:

$$
\text { Loading rate }=0.22 \times\left(K_{\text {sat }}\right)^{0.23}
$$

where loading rate is in gal day ${ }^{-1} \mathrm{ft}^{-2}$ and $K_{\text {sat }}$ is in $\mathrm{cm} \mathrm{hr}^{-1}$ (Taylor et al. 1997). This equation was derived from soil data in Wisconsin and other Midwestern states, and using soil characterization data from Purdue University for Indiana soils. According to the exponent in the equation $(0.23), K_{\text {sat }}$ will vary over five orders of magnitude while loading rates vary over one order of magnitude.

Hydraulic conductivity data have been found to follow a lognormal distribution (Rogowski 1972). Due to a large variation between mean $K_{\text {sat }}$ values, a log transformation was performed on the data (Neter et al. 1996). Log transformations were applicable because there was a large range between the largest and smallest values (Espeby 1990; Elsenbeer et al. 1992; Chappell et al. 1998; Mohanty and Mousli 2000). In order to avoid negative numbers associated with $\log$ transformations of small numbers, the $K_{\text {sat }}$ values were multiplied by 100 . The $\log _{10}$ of the data was then taken and a $t$-test $(P<0.05)$ was used to determine if significant differences existed between similar horizons of landscape positions and between horizons within a pedon.

Table 2. Results for Comparison between the Measured Loading Rate Based on $K_{\text {sat }}\left(\mathrm{LR}_{m}\right)$ and the ISDH Estimated Loading Rate $\left(\mathrm{LR}_{e}\right)$ Based on Soil Texture and Structure

\begin{tabular}{|c|c|c|c|c|c|c|c|}
\hline Horizon & $\begin{array}{c}\text { Sand } \\
(\%)\end{array}$ & $\begin{array}{l}\text { Silt } \\
(\%)\end{array}$ & $\begin{array}{l}\text { Clay } \\
(\%)\end{array}$ & Texture & Structure & $\begin{array}{c}\mathrm{Lr}_{m} \\
\left(\mathrm{~L} \mathrm{day}^{-1} \mathrm{~m}^{-2}\right) \\
\end{array}$ & $\begin{array}{c}\mathrm{Lr}_{e} \\
\left(\mathrm{~L} \mathrm{day}{ }^{-1} \mathrm{~m}^{-2}\right) \\
\end{array}$ \\
\hline \multicolumn{8}{|c|}{ Summit: Blount (fine, illitic, mesic Aeric Epiaqualf) } \\
\hline Ap & 18 & 47 & 35 & Silty clay loam & Weak, thin platy parting to weak, fine subangulary blocky & 6.35 & 24.44 \\
\hline Bt2 & 9 & 39 & 52 & Clay & Weak, coarse prismatic parting to weak, medium subangular blocky & 2.92 & 10.19 \\
\hline Cdkl & 8 & 40 & 52 & Silty clay & Weak, very coarse prismatic parting to weak, very thick platy & 3.64 & 10.19 \\
\hline Cdk3 & 9 & 41 & 50 & Silty clay & Weak, very coarse prismatic parting to weak, very thick platy & 3.40 & 10.19 \\
\hline \multicolumn{8}{|c|}{ Shoulder: Blount (fine, llitic, mesic Aerie Epiaqualf) } \\
\hline Ap & 19 & 55 & 26 & Silt loam & Weak, thin platy parting to weak, fine angular blocky & 5.65 & 24.44 \\
\hline Bt2 & 12 & 39 & 49 & Clay & Weak, coarse prismatic parting to weak, thick platy & 2.49 & 10.19 \\
\hline BCdtk & 17 & 42 & 41 & Silty clay & Weak, coarse prismatic parting to weak, thick platy & 4.08 & 10.19 \\
\hline Cdk2 & 23 & 51 & 26 & Silt loam & Weak, very coarse prismatic parting to weak, very thick platy & 3.61 & 12.22 \\
\hline \multicolumn{8}{|c|}{ Backslope: Blount (fine, illitic, mesic Aerie Epiaqualf) } \\
\hline Ap & 19 & 53 & 28 & Silty clay loam & Weak, thin platy parting to weak, medium subangulary blocky & 4.93 & 24.44 \\
\hline $\mathrm{Bt} 2$ & 28 & 38 & 34 & Clay loam & Weak, medium prismatic parting to weak, thick platy & 3.16 & 10.19 \\
\hline BCdtk & 23 & 43 & 34 & Clay loam & Weak, coarse prismatic parting to weak, thick platy & 3.55 & 10.19 \\
\hline $\mathrm{Cdk} 2$ & 22 & 43 & 35 & Clay loam & Weak, very coarse prismatic & 3.32 & 10.19 \\
\hline \multicolumn{8}{|c|}{ Footslope: Blount (fine, illitic, mesic Aeric Epiaqualf) } \\
\hline Ap2 & 18 & 53 & 29 & Silty clay loam & Weak, platy parting to weak, medium subangular blocky & 8.10 & 24.44 \\
\hline Btg2 & 11 & 44 & 45 & Silty clay & Weak, coarse prismatic parting to moderate, medium subangular blocky & 2.82 & 10.19 \\
\hline BCdtk & 8 & 38 & 54 & Clay & Weak, very coarse prismatic parting to weak, very thick platy & 3.03 & 10.19 \\
\hline Cdk2 & 7 & 39 & 54 & Clay & Weak, very coarse prismatic & 2.52 & 10.19 \\
\hline \multicolumn{8}{|c|}{ Toeslope: Pewamo (fine; mixed active, mesic Typic Argiaquoll) } \\
\hline Ap2 & 12 & 48 & 40 & Silty clay loam & Weak, thick platy parting to weak, fine, and medium subangular blocky & 7.15 & 24.44 \\
\hline Btg1 & 11 & 40 & 49 & Silty clay & Weak, coarse prismatic parting to weak, thick platy & 3.46 & 10.19 \\
\hline $\mathrm{Cd} 1$ & 10 & 41 & 49 & Silty clay & Weak, very coarse prismatic parting to weak, very thick platy & 3.09 & 10.19 \\
\hline $\mathrm{Cd} 3$ & 7 & 34 & 59 & Clay & Weak, very coarse prismatic parting to weak, very thick platy & 3.10 & 10.19 \\
\hline
\end{tabular}




\begin{tabular}{|c|c|c|c|c|c|c|c|c|c|c|c|c|c|c|c|c|}
\hline & \multicolumn{4}{|c|}{ Summit } & & & & & & & & & & & & \\
\hline & Ap & $\mathrm{Bt2}$ & Cok1 & Cdk3 & & & & & & & & & & & & \\
\hline & & & & & & & & & & & & & & & & \\
\hline & & & & & & & & & & & & & & & & \\
\hline & & & & & & & & & & & & & & & & \\
\hline ShouldeI & & & & & Shol & Ider & & & & & & & & & & \\
\hline Ap & NS & NS & NS & NS & $A p$ & Bt2 & BCottk & Cdk2 & & & & & & & & \\
\hline Bt2 & NS & & NS & NS & & & & & & & & & & & & \\
\hline BCdtk & NS & NS & NS & NS & & & & & & & & & & & & \\
\hline Cdk2 & NS & NS & NS & NS & & & & & & & & & & & & \\
\hline Backslope & & & & & & & & & Bacl & slope & & & & & & \\
\hline Ap & NS & NS & NS & NS & NS & NS & NS & NS & $A p$ & Bt2 & BCdtk & Cak2 & & & & \\
\hline $8+2$ & NS & NS & NS & NS & NS & & NS & NS & & & & & & & & \\
\hline BCotk & NS & NS & NS & NS & NS & NS & & NS & & & & & & & & \\
\hline Cdk2 & NS & NS & NS & NS & NS & NS & NS & NS & & & & & & & & \\
\hline Footslope & & & & & & & & & & & & & Foor & slope & & \\
\hline Ap2 & NS & NS & NS & NS & NS & NS & NS & NS & & NS & NS & NS & Ap2 & $B \operatorname{tg} 2$ & BCath & Cdk2 \\
\hline $8 \operatorname{tg} 2$ & NS & NS & NS & NS & NS & & NS & NS & NS & & NS & NS & & & & \\
\hline BCutk & NS & NS & & NS & NS & NS & & NS & NS & NS & & NS & & & & \\
\hline $\mathrm{Cdk2}$ & NS & NS & NS & & NS & NS & NS & & NS & NS & NS & & & & & \\
\hline Toeslope & & & & & & & & & & & & & & & & \\
\hline Ap2 & NS & NS & NS & NS & NS & NS & NS & NS & & NS & NS & NS & NS & NS & NS & NS \\
\hline Btg1 & NS & & NS & NS & NS & & NS & NSS & NS & NS & NS & NS & NS & & NS & NS \\
\hline Cd1 & NS & NS & & NS & NS & NS & & NS & NS & NS & & NS & NS & NS & NS & NS \\
\hline $\mathrm{Cd} 3$ & NS & NS & NS & & NS & NS & NS & NS & NS & NS & NS & NS & NS & NS & NS & \\
\hline
\end{tabular}

Fig. 2. Significant differences in $K_{\text {sat }}(P<0.05)$ between similar horizons of different landscape positions. $K_{\text {sat }}$ data ware converted to $\mu \mathrm{m} \mathrm{s}^{-1}$ and then multiplied by 100 . The $\log _{10}$ of the data was taken and significant differences were determined using a $t$-test at the $95 \%$ confidence level. Shaded boxes indicate a significant difference exists and "NS" indicates there is no significant difference.

\section{Results}

Results for the comparison of $K_{\text {sat }}\left(\mathrm{LR}_{m}\right)$ to morphological loading rate $\left(\mathrm{LR}_{e}\right)$ are found in Table 2 . Results showing significant differences in $K_{\text {sat }}$ between different landscape positions are found in Fig. 2. Results for comparison of measured $K_{\text {sat }}$ data to estimated $K_{\text {sat }}$ from the predicted values obtained from the pedotransfer functions are found in Fig. 3.

\section{Discussion}

\section{Comparison of $K_{\text {sat }}$ Measurements to Morphological Loading Rate}

Results indicated that for all horizons at all landscape positions, the $\mathrm{LR}_{e}$ is larger than the $\mathrm{LR}_{m}$. The $\mathrm{LR}_{e}$ indicated that all horizons would be acceptable for septic system installation (Table 2). All loading rates were greater than or equal to $10.19 \mathrm{~L} \mathrm{day}^{-1} \mathrm{~m}^{-2}$ and less than $48.89 \mathrm{~L} \mathrm{day}^{-1} \mathrm{~m}^{-2}$. All $\mathrm{LR}_{m}$ were lower than $10.19 \mathrm{~L} \mathrm{day}^{-1} \mathrm{~m}^{-2}$, indicating that no horizons at any landscape position would be acceptable for a septic system.

Results indicated that the current method of using structure and texture to determine the loading rate overestimated $K_{\text {sat }}$ for all horizons. One method of dealing with the issue of failing septic systems would be to modify the ISDH loading rate table. Even though morphological data have been used to successfully estimate $K_{\text {sat }}$ for other locations (McKeague et al. 1982), it was not adequate for this study site. Possibly the high carbonate content and clay mineralogy are factors in how water was moving through these soils. One way to modify the table would be to lower the allowable loading rate for septic system installation. If the loading rate was lowered, absorption fields would increase in size, allowing for more area to provide treatment.

\section{Determining the Best Landscape Position for Septic System Installation}

Even though all landscape positions at this study site were not suitable for septic systems, perhaps trends in $K_{\text {sat }}$ may provide some insight as to which landscape positions would be suitable at other hillslope locations. Surface horizons showed few significant differences in $K_{\text {sat }}$ across the landscape (Fig. 2), probably because the agricultural field had been plowed uniformly and the soil texture at the surface is relatively uniform (silt loam to silty clay loam, 26-40\% clay, Table 2) This is also where the fastest $K_{\text {sat }}$ occurred at each landscape position. However, significant differences in $K_{\text {sat }}$ were found between similar subsurface horizons of different landscape positions (Fig. 2). These differences between landscape positions support findings that $K_{\text {sat }}$ is significantly different across a glacial till slope transition (Espeby 1990; Mohanty and Mousli 2000). For $K_{\text {sat }}$ in the lower three subsurface horizons, the general trend showed significant differences between the upper three landscape positions (summit, shoulder, and backslope) and the lower two landscape positions (footslope and toeslope). There were several exceptions to this trend in the $\mathrm{Bt}$ horizon where the $K_{\text {sat }}$ at the summit was significantly larger than at the shoulder, and the $K_{\text {sat }}$ at the footslope was significantly smaller than at the toeslope.

Overall trends in $K_{\text {sat }}$ indicated that at the upper three landscape positions, the smallest $K_{\text {sat }}$ occurred in the Bt 2 horizon. At the lower two landscape positions, the smallest $K_{\text {sat }}$ occurred in the Cd horizons. County health departments do not allow septic 
(a) Jabro Model

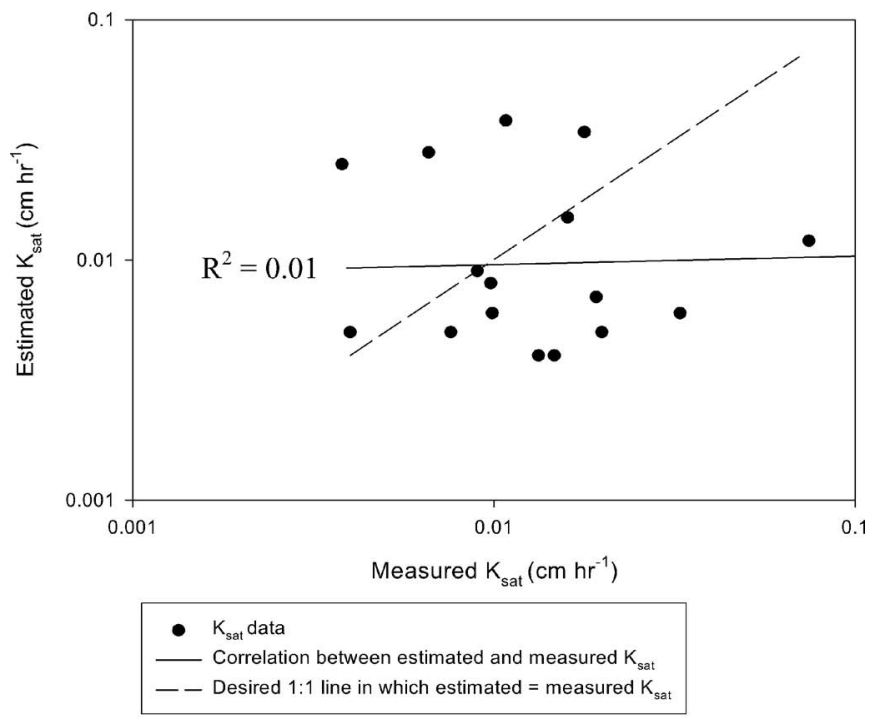

(b) Puckett Model

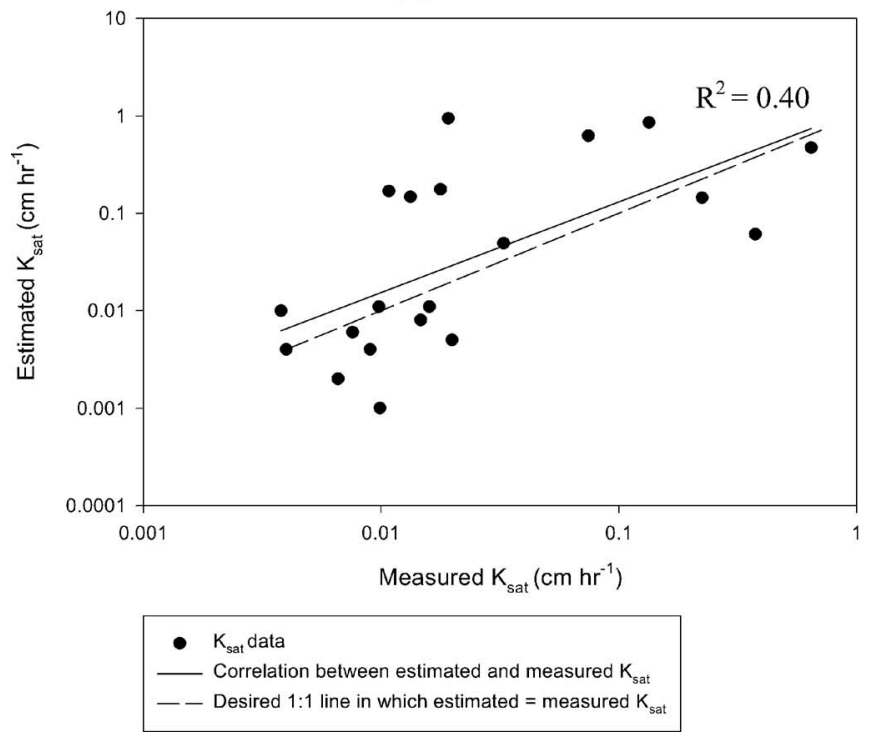

Fig. 3. Correlation between measured $K_{\text {sat }}$ and estimated $K_{\text {sat }}$ from the Jabro (a) and Puckett (b) models

systems to be installed in dense glacial till horizons. This study has shown that the surface horizons have the largest $K_{\text {sat }}$ for all landscape positions.

\section{Comparison of Estimated $K_{\text {sat }}$ from Models to Measured $K_{\text {sat }}$}

A regression analysis was used to determine which estimated values from the pedotransfer functions are better correlated with the measured values (Fig. 3). The Puckett model had a correlation coefficient equal to $R^{2}=0.40$ [Fig. 3(b)]. The Puckett model may have been closer to measured values because it is highly dependent on the percentage of clay. The soils at our study site contained a relatively high amount of clay (26-54\%). The Jabro model was less accurate $\left[R^{2}=0.01\right.$; Fig. 3(a) $]$. The significant correlation between measured $K_{\text {sat }}$ and estimated $K_{\text {sat }}$ for the Puckett model indicates that it may be a more useful tool for county health departments to determine whether septic system can be installed relative to the Jabro model. However, even though the correlation between the measured $K_{\text {sat }}$ and the Puckett model pedotransfer function was significant, regulators will probably require the model to be improved before it can be used.

\section{Conclusions}

Loading rates based on in situ $K_{\text {sat }}$ measurements were not comparable to the Indiana State Department of Health loading rate based on soil texture and soil structure. For all horizons at all landscape positions, loading rates based on field $K_{\text {sat }}$ measurements were smaller than the estimated loading rate. Results indicate that the current method of using structure and texture to determine loading rate overestimated $K_{\text {sat }}$. For this study site, there was the possibility that soil properties such as clay content and mineralogy may be a factor in water movement through these soils. It was recommended that modifications to the current ISDH loading rate table be made for these soils.

Existing pedotransfer function models have been developed to estimate $K_{\text {sat }}$. The correlation between measured $K_{\text {sat }}$ and estimated $K_{\text {sat }}$ was low, albeit significant $\left(R^{2}=0.40\right)$. An improved model will need to be developed before local regulatory personnel can utilize pedotransfer functions to assist in septic system design.

\section{References}

Acutis, M., and Donatelli, M. (2003). "SOILPAR 2.00: Software to estimate soil hydrological parameters and functions." Eur. J. Agron., 18, 373-377.

Amoozegar, A. (1989). "A compact constant-head permeameter for measuring saturated hydraulic conductivity of the vadose zone." Soil Sci. Soc. Am. J., 53, 1356-1361.

Burt, R. (2004). "Soil survey laboratory methods manual." Soil Survey Investigations Rep. No. 42, Ver. 4.0. U.S. Government Printing Office, Washington, D.C.

Campbell, G. S. (1974). "A simple method for determining unsaturated conductivity from moisture retention data." Soil Sci., 117(6), 311314.

Chappell, N. A., Franks, S. W., and Larenus, J. (1998). "Multi-scale permeability estimation for a tropical catchment." Hydrolog. Process., 12(9), 1507-1523.

Clapp, R. B., and Hornberger, G. M. (1978). "Empirical equations for some soil hydraulic properties." Water Resour. Res., 14(4), 601-604.

Elsenbeer, H., Cassel, K., and Castro, J. (1992). "Spatial analysis of soil hydraulic conductivity in a tropical rainforest catchment." Water Resour. Res., 28(12), 3201-3214.

Espeby, B. (1990). "An analysis of saturated hydraulic conductivity in a forested glacial till slope.” Soil Sci., 150(2), 485-494.

Gray, H. H. (2000). "Physiographic divisions of Indiana." Indiana Geological Survey Special Rep. No. 61, Bloomington, Ind.

Indiana State Dept. of Health (ISDH). (1990). "Residential sewage disposal systems." Rule 410 IAC 6-8.1, Indiana State Dept. of Health, Indianapolis, Ind.

Jabro, J. D. (1992). "Estimation of saturated hydraulic conductivity of soils from particle size distribution and bulk density data." Trans. ASAE, 35(2), 557-560.

McKeague, J. A., Wang, C., and Topp, G. C. (1982). "Estimating saturated hydraulic conductivity from soil morphology." Soil Sci. Soc. Am. J., 46(6), 1239-1244.

Mohanty, B. P., and Mousli, Z. (2000). "Saturated hydraulic conductivity and soil water retention properties across a soil-slope transition." Water Resour. Res., 36(11), 3311-3324. 
National Climatic Data Center (NCDC). (2005). "Indiana climate summary." National Climatic Data Center, Ashville, N.C., 〈http://www. ncdc.noaa.gov/oa/climate/research/cag3/in.html (July 26, 2005).

Neter, J. W., Kutner, M. H., Nachtsheim, C. J., and Wasserman, W. (1996). Applied linear statistical models, 4th Ed., Irwin/McGraw-Hill, Chicago.

Puckett, W. E., Dane, J. H., and Hajek, B. F. (1985). "Physical and mineralogical data to determine soil hydraulic properties." Soil Sci. Soc. Am. J., 49(4), 831-836.

Rogowski, A. S. (1972). "Watershed physics: Soil variability criteria." Water Resour. Res., 8(4), 1015-1023.
Schoeneberger, P. J., Wysicki, D. A., Benham, E. C., and Broderson, W. D. (2002). Field book for describing and sampling soils, NRCS, USDA, National Soil Survey Center, Lincoln, Neb.

Shepard, J. S. (1993). "Using a fractal model to compute the hydraulic conductivity function." Soil Sci. Soc. Am. J., 57(2), 300-306.

Taylor, C., Yahner, J., and Jones, D. (1997). "An evaluation of on-site technology in Indiana: A report to the Indiana State Dept. of Health." Purdue Univ., West Lafayette, Ind.

Wayne, W. J. (1966). "Ice and land.” Natural features of Indiana, A. A. Lindsey, ed., Indiana Academy of Science, Indianapolis, Ind. 